\title{
Perbandingan Hasil Belajar Fisika antara Model pembelajaran Aptitude Treatment Interaction (ATI) dengan Model Pembelajaran Student Teams Achievment Division (STAD) pada Siswa Kelas X SMA Negeri 1 Ampana Kota
}

\author{
Erniati, Unggul Wahyono, Nurjannah \\ Email: Erniatiposo@yahoo.co.id \\ Prodi Studi Pendidikan Fisika, Jurusan Pendidikan MIPA, Universitas Tadulako \\ Jl. Soekarno Hatta KM. 9 Kampus Bumi Tadulako Tondo Palu - Sulawesi Tengah
}

\begin{abstract}
Abstrak - Penelitian ini bertujuan untuk mengetahui ada tidaknya perbandingan hasil belajar fisika antara siswa yang mengikuti model pembelajaran Aptitude Treatment Interaction (ATI) dengan model pembelajaran Student Teams Achivment Interaction (STAD) . Metode penelitian yang digunakan adalah eksperimen kuasi, dengan desain penelitian "the non ekuivalen pretest-posttest design". Populasi dalam penelitian adalah seluruh siswa kelas X SMA Negeri 1 Ampana Kota, dengan sampel penelitian Kelas $X_{D}$ sebagai kelas eksperimen $A$ dengan jumlah siswa 26 orang dan kelas $X_{E}$ sebagai kelas eksperimen B dengan jumlah siswa 25 orang. Hasil analisa data yang diperoleh adalah hasil belajar fisika, pada kelas eksperimen A skor rata-ratanya 12,65 dengan standar deviasi 2,38 dan kelas eksperimen B skor rata-ratanya 9,76 dengan standar deviasi 2,25. Berdasarkan hasil pengujian hipotesis diperoleh $t_{\text {hitung }}=4,44$ sedangkan untuk $t_{\text {tabel }}=2,00$. Hal ini berarti bahwa hasil pengujian hipotesis berada diluar kriteria penerimaan $\mathrm{H}_{0}$. Terima $\mathrm{H}_{0}$ jika $-2,00<\mathrm{t}<2,00$ dan tolak $\mathrm{H}_{0}$ dalam hal lainnya. Di dapat bahwa $t_{\text {hitung }}=4,44$ berada diluar daerah penerimaan $\mathrm{H}_{0}$. Jadi dengan demikian $\mathrm{H}_{0}$ ditolak dalam taraf nyata $\mathrm{a}=0,05$ dengan $\mathrm{dk}=49$. Sehingga hipotesis $\mathrm{H}_{1}$ diterima. Ini berarti bahwa terdapat perbedaan hasil belajar fisika antara siswa yang mengikuti model pembelajaran Aptitude Treatment Interaction (ATI) dengan model pembelajaran Student Teams Achivment Interaction (STAD)
\end{abstract}

Kata Kunci : Aptitude Treatment Interaction (ATI), Student Teams Achivment Interaction (STAD), Hasil belajar

\section{PENDAHULUAN}

Perkembangan Ilmu Pengetahuan Alam (IPA) telah melaju dengan pesatnya, hal ini erat hubungannya dengan perkembangan teknologi. Perkembangan teknologi memberikan wahana yang memungkinkan IPA berkembang dengan pesat. Dengan perkembangan ini dapat merubah para pendidik untuk dapat merancang dan melaksanakan pendidikan yang lebih terarah. Untuk meningkatkan sumber daya manusia melalui jalur pendidikan khususnya Ilmu Pengetahuan Alam arah perkembangannya bertujuan meningkatkan keterampilan prosoes untuk memperoleh konsepkonnsep IPA dalam menumbuhkan nilai dan sikap ilmiah serta menerapkan konsep dan prinsip yang melibatkan operasi mental, keterampilan dan strategi.

Perkembangan IPA tidak hanya ditujukan oleh kumpulan fakta saja tetapi juga dipengaruhi oleh timbulnya metode ilmiah dan sikap ilmiah. Jadi, metode ilmiah itu merupakan pengetahuan yang dinamis tidak statis baik dalam teori maupun dalam praktek. Hal ini berarti bahwa proses belajar mengajar IPA-Fisika tidak hanya berlandaskan teori pelajaran perilaku, tetapi lebih menekankan pada prinsip-prinsip belajar yang menggunakan berbagai model, strategi, pendekatan, dan teknik pendekatan. Namun metode yang membuat suasanya kelas menjadi lebih aktif, pembelajaran menjadi lebih menarik yaitu dengan metode pembelajaran kelompok (belajar sosial).

Menurut Arief Rahman [1], salah seorang pengamat dunia pendidikan menyatakan bahwa model pembelajaran yang dikembangkan dewasa ini kelihatan masih belum peduli dan bahkan belum mampu mengapresiasi serta mengakomodasi perbedaan-perbedaan individual siswa, dalam melaksanakan proses belajar mengajar guru memberikan layanan pembelajaran yang sama untuk semua siswa, baik yang memiliki kemampuan tinggi, 
sedang ataupun rendah. Dengan perlakuan demikian, siswa yang berbeda kecepatan belajarnya belum mendapatkan layanan pembelajaran yang sesuai dengan kemampuan masing-masing.

Tingkat keberhasilan pelaksanaan suatu proses belajar mengajar dipengaruhi oleh banyak faktor. Diantaranya perbedaan kemampuan (aptitude) siswa, proses pembelajaran dan hasil belajar siswa sendiri. Sebagaimana diketahui bahwa setiap siswa mempunyai kemampuan yang berbeda-beda. Ada yang memiliki kemampuan tinggi dan ada yang berkemampuan rendah atau pun sedang. Oleh karena itu, untuk mengakomodasi dan mengapresiasi perbedaan individual siswa dalam pembelajaran dalam rangka mengoptimalkan hasil belajar dibutuhkan model pembelajaran yang dapat diterapkan untuk menyesuaikan pembelajaran dengan perbedaan kemampuan siswa.

Berdasarkan informasi yang penulis dapatkan dari sekolah menyatakan bahwa hasil belajar yang dicapai oleh siswa dipengaruhi oleh model pembelajaran dan kurangnya daya minat siswa dalam mengikuti materi pelajaran ataupun mengerjakan tugas. Maka penulis tertarik untuk membandingkan pembelajaran yang menggunakan model pembelajara Aptitude Treadment Interaction (ATI) dengan model pembelajaran Student Teams Achievement Division (STAD) pada siswa kelas X SMA Negeri 1 Ampana.

\section{METODOLOGI PENELITIAN}

Penelitian yang dilakukan menggunakan metode eksperimen quasi dengan menggunakan dua kelas eksperimen. Adapun desain penelitian adalah menggunakan desain penelitian "the non equivalen Pretest-Posttest Design" atau rancangan PratesPascates yang tidak ekuivalen, yaitu dengan memilih kelas-kelas yang diperkirakan sama keadaan atau kondisinya, dalam hal ini sama berdasarkan tingkat kecerdasan. Satu kelas berfungsi sebagai kelas eksperimen A dan satu kelas sebagai kelas eksperimen $B$.
ISSN 23383240

Penelitian ini dilaksanakan pada dua kelas yang terdiri dari kelas eksperimen A dan kelas eksperimen $B$, dalam desain ini kedua kelompok dipilih yang tingkat kemampuannya sama, dan diberi tes awal (Pretest) dengan tes yang sama. Kemudian kelompok eksperimen A diberi model pembelajara Aptitude Treadment Interaction (ATI), sedangkan kelompok B model pembelajaran Student Teams Achievement Division (STAD). Setelah beberapa saat, kedua kelompok dites dengan tes sama sebagai tes akhir (postest). Hasil dari kedua tes akhir dibandingkan (diuji perbedannya), demikian juga hasil tes awal dan tes akhir pada masing-masing kelompok.

Tabel 1 Desain penelitian (the non equivalen, Pretest-Postest Design)

\begin{tabular}{|c|c|c|c|}
\hline $\begin{array}{c}\text { Kelompok } \\
\text { Aksperimen } \\
\text { A }\end{array}$ & Pretest & Perlakuan & Posttes \\
\hline $\begin{array}{c}\text { Eksperimen } \\
\text { B }\end{array}$ & O & $\mathrm{X}_{1}$ & 0 \\
\hline \multicolumn{2}{|c|}{ Sumber : (Sugiyono:2010) } & 0 \\
\hline
\end{tabular}

Keterangan :

$\mathrm{X}_{1}$ :Perlakuan untuk kelompok eksperimen dengan menerapkan model pembelajaran aptitude treatment interaction (ATI)

$\mathrm{X}_{2}$ :Perlakuan untuk kelompok eksperimen dengan menerapakan model pembelajaran student teams achievement division (STAD)

0 : Pretest

O : Postest

\section{HASIL DAN PEMBAHASAN}

3.1 Hasil penelitian

Dalam bab ini akan dipaparkan data hasil penelitian selama kegiatan pembelajaran melalui model pembelajaran aptitude treatment interaction (ATI) dan model pembelajaran student times achivment devision (STAD). Data hasil penelitian yang diperoleh pada penilitian ini adalah skor hasil tes hasil belajar fisika pada materi pengukuran.

\subsubsection{Tes Awal}

Dalam penelitian ini, digunakan instrumen berupa tes hasil belajar yang terdiri dari 20 soal dalam 
bentuk pilihan ganda. Tes awal yang dilakukan bertujuan untuk mengetahui pengetahuan awal siswa sebelum diberikan perlakuan. Pembagian kelompok yang dilakukan, berdasarkan hasil tes awal. Siswa yang mendapat nilai tinggi, sedang dan rendah akan berada dalam 1 kelompok. Hal ini bertujuan agar siswa bisa saling berinteraksi antara siswa yang memiliki nilai tinggi, sedang, dan rendah.

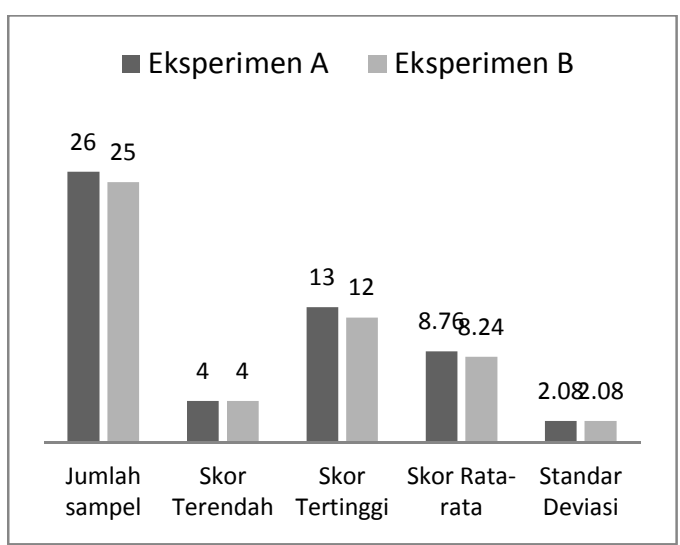

Gambar 1. Hasil Tes Awal Eksperimen A dan Eksperimen B

\subsubsection{Lembar observasi aktivitas pembelajaran}

Aktivitas guru dan siswa diperoleh melalui observasi yang dilakukan oleh seorang observer, pertemuan dilakukan sebanyak 2 kali. Setiap pertemuan menggunakan lembar observasi. Hasil observasi guru dan siswa untuk kelas eksperimen $A$ dapat dilihat pada Gambar 2.

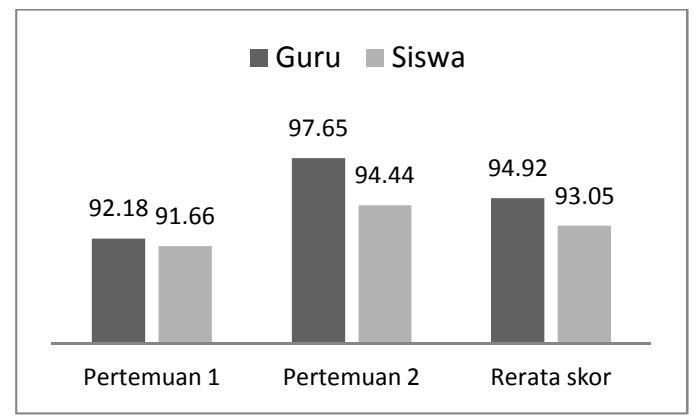

Gambar 2. Aktivitas Pembelajaran Eksperimen A

Aktivitas guru dan siswa diperoleh melalui observasi yang dilakukan oleh seorang observer, pertemuan dilakukan sebanyak 2 kali. Setiap pertemuan menggunakan lembar observasi. Hasil observasi guru dan siswa untuk kelas eksperimen B dapat dilihat pada Gambar 3.

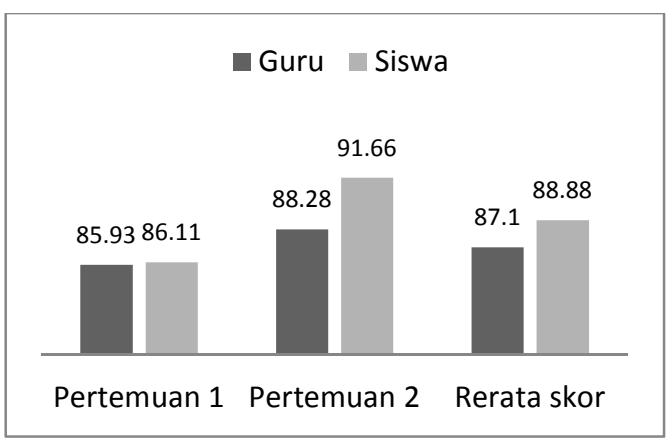

Gambar 3. Aktivitas Pembelajaran Eksperimen B

Berdasarkan aktivitas guru dan siswa di atas, terlihat bahwa presentase jumlah skor yang diperoleh untuk aktivitas guru lebih besar dibandingkan dengan siswa. Hal ini disebabkan karena siswa masih kurang mampu dalam mengemukakan pendapat, sebab kemampuan dasar siswa rendah. Bekerja kelompok, hanya satu atau dua orang saja yang aktif, sedangkan yang lainnya membicarakan hal lain yang tidak berhubungan dengan tugas kelompok. Dalam melaksanakan diskusi kelompok, peneliti juga melihat di antara anggota kelompok ada yang suka mengganggu teman karena mereka beranggapan bahwa dalam diskusi tidak perlu semuanya bekerja. Tidak semua anggota kelompok yang aktif, tanggung jawab dalam kelompok menjadi kurang.

\subsubsection{Tes Akhir}

Setelah diberikan perlakuan untuk kedua kelas tersebut, siswa diberikan tes hasil belajar untuk melihat perbedaan hasil belajar siswa antara kedua kelas tersebut, maka diperoleh data hasil penelitian untuk masing-masing kelas ekperimen pertama dan kedua seperti pada Gambar 4. 


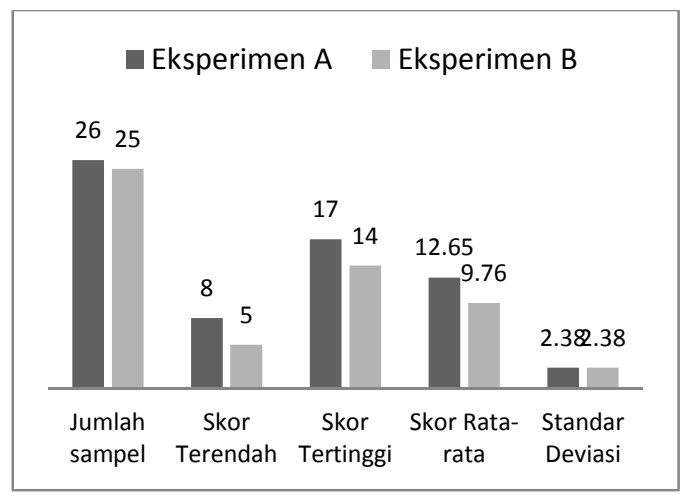

Gambar 4. Hasil Tes Akhir Eksperimen A dan Eksperimen B

Adapun presentasi skor rata-rata Tes Awal dan Tes Akhir dari kedua kelas dapat dilihat pada Gambar 5.

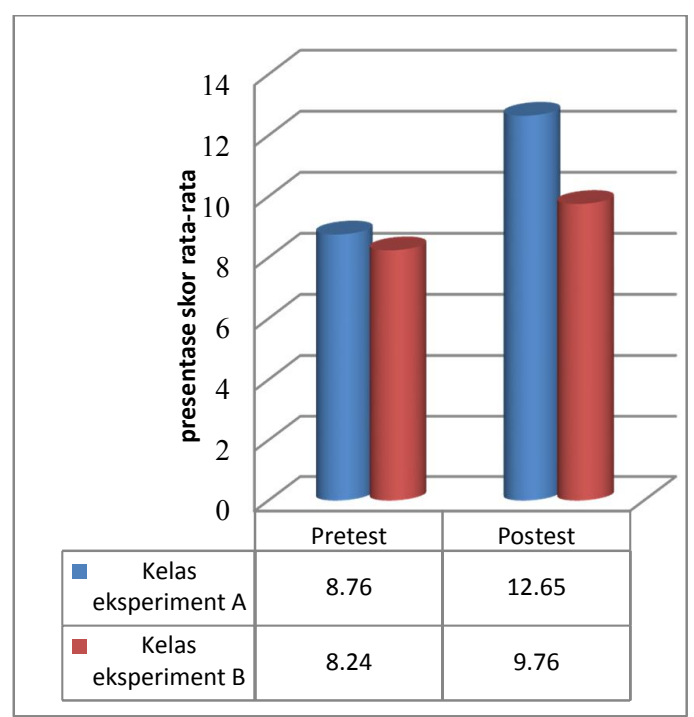

Gambar 5. Grafik Perolehan Rata-rata Tes Awal dan Tes Akhir dari Kedua Kelas Eksperimen

Berdasarkan gambar 5, presentase skor rata-rata dan standar deviasi tes hasil belajar untuk Tes Akhir pada kelas eksperimen pertama 12,65 dan pada kelas eksperimen kedua 9,76 dan standar deviasi 2,38. Dapat dilihat bahwa tes hasil belajar untuk kelas eksperimen A lebih besar dari pada kelas eksperimen B. Secara kuantitas terdapat perbedaan tes hasil belajar fisika antara kelas eksperimen pertama dengan kelas eksperimen kedua.

\subsubsection{Uji Normalitas}

ISSN 23383240

Menguji normalitas suatu data hasil penelitian ini digunakan persamaan chi kuadrat. Data yang digunakan untuk uji normalitas meliputi 1) tes awal hasil belajar untuk kelas eksperimen $A$ dan kelas eksperimenB, 2) tes akhir hasil belajar untuk kelas $A$ dan kelas eksperimen $B$. Diperoleh hasil pengujian normalitas seperti disajikan Tabel 2.

Tabel 2 Uji Normalitas Data Tes Hasil Belajar Fisika pada Kelas Eksperimen A dan Eksperimen B

\begin{tabular}{|c|c|c|c|c|}
\hline \multirow{2}{*}{ Uraian } & \multicolumn{2}{|c|}{ Pretest } & \multicolumn{2}{c|}{ Posttest } \\
\cline { 2 - 5 } & $\begin{array}{c}\text { Eksperi } \\
\text { men A }\end{array}$ & $\begin{array}{c}\text { Eksperim } \\
\text { en B }\end{array}$ & $\begin{array}{c}\text { Eksperi } \\
\text { men A }\end{array}$ & $\begin{array}{c}\text { Eksperi } \\
\text { men B }\end{array}$ \\
\hline Sampel & 26 & 25 & 26 & 26 \\
$X^{2}$ hitung & 1,27 & 1,12 & 2,23 & 1,65 \\
$X^{2}$ tabel & 5,99 & 5,99 & 5,99 & 5,99 \\
$\begin{array}{c}\text { Keteranga } \\
\text { n }\end{array}$ & Normal & Normal & Normal & Normal \\
\hline
\end{tabular}

Pengujian normalitas pada kelas eksperimen pertama dengan $\mathrm{dk}=(5-3)=2$ dan taraf signifikan 0,05 , diperoleh $\chi 2_{\text {hit }}=2,23$ sedangkan $\chi 2_{\text {tabel } 0,95(2)}=$ 5,99. Karena $\chi 2_{\text {hit }}<\chi 2_{\text {tabel } 0,95(2)}$, maka data berdistribusi normal. Pada kelas eksperimen kedua, $\mathrm{dk}=(5-3)=2$ dan taraf signifikan 0,05, diperoleh $X^{2}{ }_{\text {hit }}=1,65$ sedangkan $\chi 2_{\text {tabel } 0,95(2)}=5,99$. Karena $\chi 2_{\text {hit }}<\chi 2_{\text {tabel } 0,95(2)}$ maka data berdistribusi normal.

\subsubsection{Uji Homogenitas Varians Data}

Menguji homogenitas varians data tes hasil belajar antara kelas eksperimen $\mathrm{A}$ dan kelas eksperimen B menggunakan uji Fisher (uji F). Diperoleh hasil seperti ditunjukkan pada Tabel 3.

Tabel 3. Uji Homogenitas Data Tes Awal dan Tes Akhir Hasil Belajar Fisika pada Kelas Eksperimen A dan Eksperimen B

\begin{tabular}{|c|c|c|}
\hline Uraian & Tes Awal & Tes Akhir \\
\hline Fhitung & 1,15 & 1,11 \\
\hline Ftabel & 1,92 & 1,92 \\
\hline
\end{tabular}

Pada pengujian homogenitas varians data dengan taraf signifikan 0,05 pada kelas eksperimen A dan B, nilai Fhitung yang diperoleh untuk tes awal adalah 1,15 dan untuk tes akhir adalah 1,11. Dengan kriteria pengujian $\mathrm{H}_{\mathrm{o}}$ diterima jika $\mathrm{F}_{(1-\alpha)\left(\mathrm{n}_{1}-1\right)}<\mathrm{F}<$ $\mathrm{F}_{\left(\frac{1}{2} \alpha\right)\left(\mathrm{n}_{1}-1\right)\left(\mathrm{n}_{2}-2\right)}$ dari Tabel 3 dapat dilihat bahwa Fhitung berada pada daerah penerimaan $\mathrm{H}_{\mathrm{o}}$ dengan demikian 
data tersebut menunjukkan kedua kelas yang dijadikan sampel berasal dari populasi yang homogen.

\subsubsection{Uji Hipotesis}

Pengujian hipotesis menggunakan statistik parametrik ( $u j i-t)$ dua variabel terikat ( $u j i$ dua pihak) dilakukan setelah diperoleh bahwa hasil data kemampuan memecahkan masalah antara kelas eksperimen A dan kelas eksperimen B berdistribusi normal dan homogen.

Hasil perolehan pengujian statistik data hasil belajar fisika antara kelas eksperimen pertama dan kelas eksperimen kedua ditunjukkan pada Tabel 4.

Tabel 4. Data Hasil Belajar Fisika antara Kelas Eksperimen A dan Kelas Eksperimen B

\begin{tabular}{|l|c|c|}
\hline & Tes Awal & Tes Akhir \\
\hline thitung & 0.89 & 4,44 \\
$t_{\text {tabel }}$ & 2,00 & 2,00 \\
Ho & Diterima & Ditolak \\
\hline
\end{tabular}

Pengujian hipotesis yang dilakukan pada taraf signifikan $(a=0,05)$ dan $d k=(26+25)-2=49$ dengan kriteria pengujian yakni, $\mathrm{H}_{0}$ diterima jika $-\mathrm{t}_{(1-}$ $0,5 a)<t<t_{(1-0,5 a)}$. Untuk pengujian hipotesis berdasarkan tes awal dengan menggunakan rata-rata skor diperoleh thitung $=0,89$ dan tabel $=2,00$ maka, $\mathrm{H}_{\circ}$ diterima dan hipotesis satu $\left(\mathrm{H}_{1}\right)$ ditolak. Artinya tidak terdapat perbedaan hasil belajar antara kelas eksperimen A dan kelas eksperimen B.

Pengujian berdasarkan tes akhir dengan menggunakan rata-rata skor diperoleh thitung $=4,44$ dan tabel $=2,00$ maka, $\mathrm{H}_{\mathrm{o}}$ ditolak dan hipotesis satu $\left(\mathrm{H}_{1}\right)$ diterima. Artinya terdapat perbedaan hasil belajar antara siswa yang diberi perlakuan pembelajaran melalui model pembelajan aptitude treatment interaction (ATI) dan siswa yang diberi perlakuan dengan model pembelajaran student times achivment devision (STAD).

\subsection{Pembahasan}

Berdasarkan hasil pengujian normalitas untuk kedua kelas ekperimen diperoleh pada kelas eksperimen pertama $\chi_{\text {hitung }}^{2}=2,23$ dan eksperimen kedua $\chi_{\text {hitung }}^{2}=1,65<\chi_{\text {tabel } 0,95}^{2}$ menunjukkan bahwa
ISSN 23383240

data berdistribusi normal pada taraf nyata 0,05. Hasil dari pengujian homogenitas dengan menggunakan uji Feisher (uji F). Pengujian homogenitas varians pada kelas ekperimen pertama dan kedua diperoleh tes awal adalah 1,15 dan tes akhir 1,11 dengan kriteria pengujian $\quad F_{(1-\alpha)(n-1)}<F<F_{\left(\frac{1}{2} \alpha\right)\left(n_{1}-1\right)\left(n_{2}-2\right)} \quad$ yang menunjukkan kedua kelas yang dijadikan sempel berasal dari populasi yang homogen, baik itu dari ekperimen pertama maupun eksperimen kedua.

Pada hasil analisis pengujian hipotesis bahwa terdapat perbedaan hasil belajar fisika yang dicapai oleh siswa yang mengikuti model pembelajaran aptitude treatment interaction (ATI) dan model pembelajaran student times achivment devision (STAD). Hal ini dapat dilihat dengan pengujian secara statistik menggunakan uji-t (uji dua pihak). Pengujian hipotesis dilakukan pada taraf nyata 0,05 dan $\mathrm{dk}=49$ diperoleh pengujian hipotesis pada tes awal adalah $t_{\text {hitung }}=0,89$ dan $t_{\text {tabel }}=2,00$ maka $\mathrm{H}_{0}$ diterima dan hipotesis satu $\mathrm{H}_{1}$ di tolak, artinya tidak terdapat perbedaan hasil belajar antara kelas ekperimen A dan B. Pada pengujian tes akhir di peroleh $t_{\text {hitung }}=4,44$ dan $t_{\text {tabel }}=2,00$ maka $\mathrm{H}_{0} \mathrm{di}$ tolak dan hipotesis satu diterima, artinya terdapat perbedaan hasil belajar antara siswa yang diberi perlakuan melalui model pembelajaran aptitude treatment interaction (ATI) dan model pembelajaran student times achivment devision (STAD). Hasil penelitian memperlihatkan adanya perbedaan hasil belajar antara siswa yang mengikuti model pembelajaran aptitude treatment interaction (ATI) dan model pembelajaran student times achivment devision (STAD).

Berdasarkan hasil analisis data tes akhir hasil belajar fisika, skor rerata dan standar deviasi tes akhir pada kelas eksperimen A yang menggunakan model pembelajaran aptitude treatment interaction (ATI) dan kelas eksperimen B yang menggunakan model pembelajaran student times achivment devision (STAD). Pada kelas eksperimen A yaitu 12,65 dan kelas eksperimen B yaitu 9,76. Hal ini 
menunjukkan tes hasil belajar antara kedua kelas berbeda setelah mendapatkan perlakuan.

Perbedaan hasil belajar ini terjadi karena pada siswa kelas eksperimen A diterapkan model pembelajaran aptitude treatment interaction (ATI) yang sesuai pelaksanaan kegiatan belajar mengajar yaitu siswa dibagi sesuai dengan karakteristik kemampuan (aptitude), lalu diberi pembelajaran atau perlakuan-perlakuan (treatments) yang berbedabeda. Siswa yang berkemampuan tinggi, pembelajarannya diarahkan kepada belajar mandiri (self learning). Sedangkan untuk siswa yang berkemampuan sedang dan rendah untuk kesempatan pertama digabungkan dan diberikan pembelajaran secara konvensional (regular teaching). Kemudian siswa yang berkemampuan rendah diberi perlakuan khusus berupa pembelajaran atau tugas tambahan.

Pada penelitian eksperimen $B$, proses pembelajaran berlangsung diterapkan model pembelajaran student times achivment devision (STAD). Siswa ditempatkan dalam kelompok belajar beranggotakan empat dan lima orang siswa yang merupakan camapuran dari kemampuan akademik yang berbeda sehingga dalam tiap kelompok memiliki variasi kemmpuan berbeda-beda.

Setelah kedua kelas diberi perlakuan yang berbeda yaitu kelas eksperimen A dengan menggunakan model pembelajaran aptitude treatment interaction (ATI) dan kelas eksperimen $\mathrm{B}$ menggunakan model pembelajaran student times achivment interaction (STAD). Kemudian diberikan tes akhir diperoleh rata-rata skor tes akhir yang berbeda. Tes yang digunakan pada dua kelas berupa tes hasil belajar pilihan ganda yang telah di uji validitasnya dan reabilitasnya.

\section{KESIMPULAN DAN SARAN}

4.1 Kesimpulan

Berdasarkan hasil penelitian dan analisis data hasil penelitian, maka dapat disimpulkan bahwa
ISSN 23383240

terdapat perbedaan hasil belajar fisika antara model pembelajaran aptitude treatment interaction (ATI) dengan model pembelajaran student teams achivment division (STAD) pada siswa kelas X SMA Negeri 1 Ampana kota. Hal ini dapat diketahui melalui hasil pengujian statistik dengan menggunakan uji-t dua variabel dimana -t $\left(\begin{array}{ccc}1-1 / 2 & \alpha\end{array}\right)$ $<\mathrm{t}<\mathrm{t}(1-1 / 2 \alpha)$ atau $-\mathrm{t}_{\text {tabel }}=2,00<\mathrm{t}$ hitung $=4,44$ $<\mathrm{t}$ tabel $=2,00 \mathrm{H}_{\mathrm{o}}$ ditolak dan $\mathrm{H}_{1}$ diterima.

\subsection{Saran}

Model pembelajaran aptitude treatment interaction (ATI) dengan model pembelajaran student teams achivment division (STAD) dapat dijadikan alternatif sebagai pertimbangan dan acuan pembelajaran bagi para guru mata pelajaran fisika pada materi yang lain untuk melatih kemampuan fisika dalam memecahkan masalah secara sistematis.

\section{DAFTAR PUSTAKA}

[1] Agus Muhammad. (1998). Perbedaan Hasil Belajar Fisika Siswa Melalui Pembelajaran Intelegency Groupingdengan Kooperatif Tipe STAD Siswa SMA Negeri 1 Banawa. Desember 2009

[2] Arikunto. (2006). Prosedur Penelitian. Jakarta: PT Rineka Cipta

[3] Rusman. (2010). Model-model Pembelajaran (mengembangkan profesionalisme guru). Jakarta: PT Raja Gafindo Persada

[4] Sudjana. (2005). Metode Statistika. Bandung: CV Tarsito.

[5] Yuliantri M, Mimi. (2012). Pengaruh model pembelajaran kooperatif tipe STAD (Student Teams Achievement Division) berbantuan media visual terhadap peningkatan keterampilan berpikir kritis pada siswa kelas X SMA 1 Dampelas. September 2011. 